\title{
DISPARITY IN CREATIVE ABILITIES AMONG RURAL AND URBAN SECONDARY SCHOOL STUDENTS IN DIBRUGARH DISTRICT OF ASSAM Manisha Das $^{1 *}$, Mukut Hazarika ${ }^{2}$
}

\author{
${ }^{1 *} \mathrm{Ph} . \mathrm{D}$. Scholar, Dept. of Education, Dibrugarh University, Assam, India; ${ }^{2}$ Prof. Dept. of Education, Dibrugarh University, \\ Assam, India. \\ Email: ${ }^{1 *}$ manisha_das@dibru.ac.in, ${ }^{2}$ mukuthazarika@dibru.ac.in
}

Article History: Received on $22^{\text {nd }}$ May 2020, Revised on 25 ${ }^{\text {th }}$ June 2020, Published on $29^{\text {th }}$ June 2020

\begin{abstract}
Purpose of the Study: This study investigated the creative abilities of students from rural and urban secondary schools in terms of their fluency, flexibility, originality, inquisitiveness, and persistency.

Methodology: The research design used here is quantitative with the type of descriptive survey method. The research subjects were 720 secondary school students selected through disproportionate stratified random sampling. The research instrument used is the Passi Test of Creativity (verbal \& non-verbal). The analysis techniques employed are descriptive statistics and inferential statistics in the form of independent means t-test.
\end{abstract}

Main Findings: The study revealed that rural and urban Secondary level school students have significant differences in their creativity. However, concerning the inquisitiveness dimension of creativity, the study reported no significant difference between the rural and urban Secondary level school students.

Applications of this Study: This research can be used as input for the schools and teachers at the secondary level to consider the practice of offering a more stimulating environment to students hailing from rural backgrounds. This research can also be used as input in the facilitation of students' creative abilities.

Novelty/Originality of this Study: The teachers, educators, and school authorities, especially at Secondary level of Education; are suggested to offer more exposures and stimulating environments to students belonging to the rural backgrounds. The study examined for the first time the rural-urban disparity among secondary level school students on the dimensions of creativity such as inquisitiveness and persistence, especially in north-east India.

Keywords: Creativity, Secondary School Student, Fluency, Flexibility, Originality, Inquisitiveness, Persistency.

INTRODUCTION

Life would have been very dull and unattractive if people have not inquired and found something unique in the realm of life. Creativity, which is so fascinating for all time and all ages, enriches the culture and hence improves the quality of human experiences (Csikszentmihalyi, 2013). It is the inventive mind of the individual that creates civilization and changes the face of history (Hildreth, 1966). From the discovery of fire to the latest technological innovations, it is human creativity that has helped humankind in its evolution from the animal living to today's modern living. People use their creativity whenever they face new challenges, and try to improve their immediate surroundings (Sternberg \& Kaufman, 2018). It is such a critical capacity that helps individuals to express and entertain themselves or others (Sternberg \& Kaufman, 2018). Sternberg \& Lubart in 1999 viewed creativity as the main driving force behind every scientific, technological, and cultural innovation (Han, Zhang, Feng, Gong, Peng \& Zhang, 2018).

Creativity involves the capacity to produce novel and original ideas or products, perceive new connections, and establish unique relationships among seemingly distinct factors. Hence, creativity is bringing something new into the world, which is mostly original and relevant. But, not all creative thinking is the world-shattering in its effects on human progress and societal development (Hildreth, 1966). As such, there are modest levels of the invention as well as the rare heights of creative genius (Hildreth, 1966). In this context, it is worthwhile to mention Beghetto and Kaufman's (2014) proposed four levels of creativity. "Big C" level referring to the eminent creative genius like Albert Einstein, "Pro C" level referring to individuals expert in their respective fields such as scientist, artist, painter, "little-c" level considered as creative by one's peers or mates such as the winner of a school competition, and "mini-c" level recognizing individuals who use creativity for their learning (Ahmadi \& Besançon, 2017). Beghetto and Kaufman (2014) further said children mostly show either "little-c" or "mini-c" (Ahmadi \& Besançon, 2017). Furthermore, by children's creativity, mostly "everyday" forms of original thinking and problem-solving capacity are referred, which is comparable with what Beghetto and Kaufman called "little-c" or "mini-c" (Kupers, Wermser, McPherson \& Geert, 2019).

Guilford (1958) equated divergent thinking ability with creative thinking. Torrance perceived creativity as a process of becoming responsive to problems, inadequacies, and gaps in knowledge, disharmonies, missing element and thus leading towards the identification of the difficulty, working for solutions or finding answers, making guesses and framing 
hypotheses, possibly modifying and retesting them and finally publicizing the findings (Götz, 1981). Drevdahl (1956) described creativity as a capacity of the individual to create compositions, products, or primarily new ideas, or novel and previously unknown to the creator.

Hence, producing something new, original, or unique in any field such as literary, arts, or science is the core of creativity. When psychologists tried to explain the meaning of creativity, they usually turned to terms like fluency, flexibility, originality, sensitivity to problems, elaboration, and redefinition (French,1959). Guilford, Wilson \& Christensen (1952) also suggested the list of traits associated with creativity such as the ability to perceive problems, fluency of ideas and expression, originality, flexibility, ability to redefine, to improvise, variability in thinking, to use familiar objects in novel forms and the ability to elaborate (Hildreth,1966).

Individuals are not all alike. Although people are individually different concerning their psychological traits, yet every one of us is, to some extent, creative because all of us create answers to various problems as we live (Haefele, 1962). Though relatively few people are intellectually creative, even ordinary folks also have a flair for self-expression in one or the other direction, such as thinking of a unique way to arrange flowers, adding a different twist in a cooking recipe, etc. (Hildreth, 1966). Kaufman \& Sternberg (2007), in their article, addressed the commonly found misconception about creativity i.e., creativity is reserve for few peculiarly gifted persons. Guilford (1962) mentioned that creativity is not only reserved for a few talented persons, but people in general also possess some degree of the same creative traits (French, 1959). Bono (2000) also viewed creativity as a reasonable and necessary part of everyone's thinking. So, the belief that every individual has the spark to be creative is remained unchanged (Lin, 2011). The potential for creativity exists within each individual, yet there is a considerable amount of individual variations about the type and amount of original product that is produced over a lifetime (Abraham, 2015). Creativity is the genesis of all societal growth and progress (Nakano \& Wechsler, 2018). Creativity is even considered as vital to the economy (Eisler, Donnelly \& Montuori, 2016). Creative development is not just a matter of chance (French, 1959; Shaheen, 2010). Circumstance or environment of an individual plays an important role in the functioning of creative ability (Simpson, 1922; Rogers, 1954). Moreover, Beghetto, Kaufman \& Baer in 2014 said that students' creativity is influenced by many factors including the environment ( $\mathrm{Wu}$, Siswanto \& Solikin, 2018). Therefore, creativity can be developed (Guilford, 1958; Parnes, 1961; Torrance, 1998; Iandoli, 1994; Kaufman \& Sternberg, 2007) and its development cannot leave to chance or mythology (Shaheen, 2010). Henceforth, creativity needs to develop to equip our future generations for their meaningful survival in this twenty-first century age (Shaheen, 2010).

\section{RESEARCH GAP AND PURPOSE OF THE STUDY}

Though many researchers across the globe tried to explore various facets of creativity, yet very few studies have been done to examine the creativity concerning locale. The studies that decided to explore creativity in the context of locality mainly concentrated on the comparison of the fluency, flexibility, originality dimension of creativity, and composite creativity between rural and urban groups. But, studies on the comparison of persistence and inquisitiveness dimension of creativity among rural and urban subjects are undoubtedly rare in both Western and Indian research literature. In this context, the present study bears newness in the context of social and educational significance. As such, the present study is designed to investigate the creative abilities of students from rural and urban secondary schools of Dibrugarh district of Assam in terms of their fluency, flexibility, originality, inquisitiveness, and persistency dimensions.

\section{REVIEW OF RELATED LITERATURE}

Creativity is an exciting issue of research across the universe. The systematic work on creativity was first moved in 1950 when Guilford became the President of the American Psychological Association (APA) (Rhodes, 1961). Since then, the door for many kinds of research on creativity has opened.

Patel (1999) studied the creativity of the B.C. community and non-B.C. community students of Secondary schools of Kaira district, Gujarat. The study revealed a significant difference among students of rural and urban locality on their creativity. The survey conducted by Thabor (2003) showed a significant difference in the creative thinking ability of rural and urban Secondary school students of East Khasi Hills district, Meghalaya. Abirami (2012), in her study, reported that urban and rural high school students differ significantly in their creativity. In the study, she reported that students hailing from the urban locality were more sociable, reflective, and ascendant because of the reason that the urban environment was more stimulating as well as conducive for creative development. Kalita (2013) also studied the creativity of adolescents in Kamrup Metro, Assam. The study reported that urban adolescents were better than the rural adolescents on the dimensions of verbal creativity, in contrast, no significant difference is revealed between rural and urban adolescents on the aspects of non-verbal creativity and composite creativity. Joseph (2015) also reported that class IX students of Northern Kerala differ significantly on creativity scores concerning their locale. Reddy (2015) also found the urban high school students as better than their rural counterparts in all the components of creativity such as fluency, flexibility, originality, and composite creativity. Sudhir \& Khiangte (1997) found highly creative girls of urban locality more superior in terms of intelligence, conscientiousness, etc. than the highly creative girls of the rural locality. Kumar \& Kumari (2014) compared the originality dimension of creativity 
between rural and urban Secondary school students. Their study revealed that urban students are significantly superior to rural students on the originality dimension of creativity. Reddy, Viswanath \& Reddy (2015) studied the non-verbal creativity of high school students. Their study found a significant difference between urban and rural students on fluency, flexibility, originality, and composite non-verbal creativity. Kumar \& Kumari (2016) in their study reported a significant difference between urban and rural school students on their divergent thinking i.e. creativity. Chauhan \& Sood (2018) in their study of non-verbal creativity among Secondary school students concerning locale revealed that rural Secondary school students scored better than their urban counterparts on originality dimension and total creativity. Mehta \& Khajuria (2018) found a significant difference between rural and urban students on their creativity.

On the contrary, Bhogayata (1986) revealed that urban and rural Secondary school students did not differ significantly on creativity. Jha (2012) reported that area or locality did not influence the creativity of high school students of Ahmedabad. Das (2012) did a study on the creativity of B.Ed students of Kamrup district, Assam. The study revealed no significant difference between rural and urban B.Ed students on their creativity. Likewise, Surapuramath (2014) also reported that rural and urban $8^{\text {th }}$ standard students did not differ significantly in their creativity.

Furthermore, despite divergence in opinions among psychologists regarding the concept of creativity, there is unanimity about certain traits that are associated with creativity. As such, creativity has been linked to certain traits such as fluency, flexibility, originality, etc. (Hildreth, 1966). Fluency is an important trait of creativity (Guilford, 1958). Torrance (1968) conceptualized fluency as the ability to think of a large number of ideas or possible solutions (Ai,1999). Flexibility has also been linked to creativity (Guilford, 1958). According to Guilford (1968), flexibility refers to the variety of ideas given and it is often linked with creative problem solving (Runco, Noble, Palmon, Acar, Ritchie \& Yurkovich, 2011). In a similar vein, Torrance (1968) also conceptualized flexibility as the ability to think of diverse approaches or strategies (Ai, 1999). Originality is also considered as the key to creativity (Runco, Noble, Palmon, Acar, Ritchie, \& Yurkovich, 2011). Originality is often labeled as a novelty (Runco \& Jaeger, 2012). Torrance (1995) defined originality in terms of the unusualness or uniqueness of ideas. Kim (2019) found that gifted children are inquisitive visionaries with insatiable curiosities for an idea. Curiosity the synonym for inquisitiveness according to Longman Dictionary of Contemporary English is considered central to the creative process as stated by Simpson in 1922 (Prakash, 2007), Plucker \& Renzulli, 1999; Almeida \& Wechsler, 2015; Nakano \& Wechsler, 2018. Albert Einstein even called his intense desire to seek answers as a holy curiosity (Iandoli, 1994). A persistent attitude is also considered as an important characteristic of the creative personalities (Abirami, 2012; Kim, 2019); Plucker \& Renzulli, 1999; Almeida \& Wechsler, 2015; Nakano \& Wechsler, 2018. Kim (2019) viewed a persistent attitude as continuously committed to one's goal.

\section{METHODOLOGY}

This study was conducted using a descriptive research method. Descriptive research is characterized by measurement, classification, analysis, comparison, and interpretation of data.

This research was aimed at investigating the creative abilities of students from rural and urban secondary schools of Dibrugarh district of Assam in terms of fluency, flexibility, originality, inquisitiveness, and persistency dimensions. Therefore, the result of this research was obtained by gathering data from a sample of 720 students from 36 secondary schools of the Dibrugarh district of Assam using the Passi Test of Creativity (verbal \& non-verbal). The participants for this research were selected by using disproportionate stratified random sampling.

For this research, the researchers gathered the requisite data using the Passi Test of Creativity (verbal \& non-verbal). This Test is a Test Battery comprising of six sub-tests such as (i) The Seeing Problems Test, (ii) The Unusual Uses Test, (iii) The Consequences Test, (iv) Test of Inquisitiveness, (v) The Square Puzzle Test \& (vi)The Blocks Test of Creativity, intended to measure creativity in school children in terms of the fluency, flexibility, originality, inquisitiveness and persistency dimensions. The first three sub-tests are verbal, in which the participants had to write down their responses and the last three sub-tests are mostly non-verbal because the test materials of these three sub-tests present the non-verbal stimuli to the participants in the forms of wooden blocks, plastic made right-angled triangles and quadrilaterals, electronic metronome.

The result of this research was analyzed through a quantitative method by employing both descriptive and inferential statistics in the form of independent means t-test.

\section{RESULTS AND DISCUSSION}

The results of the research are shown in the following tables.

\section{Level of Creativity of Rural and Urban Secondary school students of Dibrugarh district, Assam}

Descriptive statistics was launched to investigate the level of creativity of rural and urban secondary school students of the Dibrugarh district of Assam. Table 1 is depicting the level of creativity of rural secondary school students while Table 2 is showing the level of creativity of urban secondary school students. 
Table 1: Level of creativity of Rural Secondary school students of Dibrugarh District, Assam

\begin{tabular}{llllllc}
\hline Variable & $\begin{array}{l}\text { No of Students } \\
(\mathbf{N})\end{array}$ & Mean & Median & SD & Skewness & Kurtosis \\
\hline Creativity & 360 & 47.178 & 46.0 & 19.820 & 0.745 & 1.454 \\
\hline
\end{tabular}

Table 2: Level of creativity of Urban Secondary school students of Dibrugarh District, Assam

\begin{tabular}{lllllll}
\hline Variable & $\begin{array}{l}\text { No of Students } \\
(\mathbf{N})\end{array}$ & Mean & Median & SD & Skewness & Kurtosis \\
\hline Creativity & 360 & 52.931 & 51.50 & 22.601 & 0.389 & -0.100 \\
\hline
\end{tabular}

The descriptive statistics presented in Table $1 \&$ Table 2 demonstrated that urban secondary school students had a better mean creativity score $(M=52.931)$ than the rural secondary school students who had a mean creativity score $(M=47.178)$. Besides, the results presented in Table 1 and Table 2 revealed that the urban secondary school students had better creativity in comparison to rural secondary school students.

\section{Comparison of Creativity of Rural and Urban Secondary school students of Dibrugarh district, Assam}

Inferential statistics i.e. independent means t-test was employed to investigate the differences in the creative abilities of students from rural and urban secondary schools of Dibrugarh district of Assam. The results of this statistical test are shown in Table 3 and Figure 1.

Table 3: Comparison of Creativity of Rural and Urban Secondary school students of Dibrugarh district, Assam

\begin{tabular}{llllllllll}
\hline Variable & Locality & N & Mean & SD & $\begin{array}{l}\text { Mean } \\
\text { Difference }\end{array}$ & SE $_{\mathbf{D}}$ & t & df & Inference \\
\hline Creativity & Rural & 360 & 47.178 & 19.820 & 5.753 & 1.584 & 3.631 & 718 & $\begin{array}{l}\text { Significant } \\
\text { at } 0.05 \text { level }\end{array}$ \\
\cline { 2 - 5 } & Urban & 360 & 52.931 & 22.601 & & & & & \\
\hline
\end{tabular}

According to the results depicted in Table 3, the calculated t-value (3.631) which is significant at 95\% confidence level revealed a statistically significant difference in the creativity of students from rural and urban secondary schools of Dibrugarh district of Assam.



Figure 1: Comparison of Creativity of rural and urban secondary school students

Comparison of Mean scores on Fluency, Flexibility, Originality, Inquisitiveness \& Persistency dimension of Creativity between Rural and Urban Secondary school students of Dibrugarh district, Assam: 
Descriptive statistics and inferential statistics in the form of independent means t-test was also employed to compare the creative abilities of students from rural and urban secondary schools in terms of fluency, flexibility, originality, inquisitiveness, and persistency dimensions. The results are shown in Table 4 and Figure 2.

Table 4: Comparison of Mean Scores on various dimensions of creativity between Rural and Urban Secondary school students

\begin{tabular}{|c|c|c|c|c|c|c|c|c|c|}
\hline Dimension & Locality & $\mathbf{N}$ & Mean & SD & $\begin{array}{l}\text { Mean } \\
\text { Difference }\end{array}$ & $\mathbf{S E}_{\mathrm{D}}$ & $\overline{\mathbf{t}}$ & df & Inference \\
\hline \multirow[t]{2}{*}{ Fluency } & Rural & 360 & 21.297 & 10.418 & 2.597 & 0.816 & 3.183 & 718 & $\begin{array}{l}\text { Significant } \\
\text { at } 0.05 \\
\text { level }\end{array}$ \\
\hline & Urban & 360 & 23.877 & 11.427 & & & & & \\
\hline \multirow[t]{2}{*}{ Flexibility } & Rural & 360 & 6.269 & 2.177 & 0.538 & 0.176 & 3.056 & 718 & $\begin{array}{l}\text { Significant } \\
\text { at } 0.05 \\
\text { level }\end{array}$ \\
\hline & Urban & 360 & 6.805 & 2.530 & & & & & \\
\hline \multirow[t]{2}{*}{ Originality } & Rural & 360 & 12.702 & 6.969 & 1.853 & 0.572 & 3.239 & 718 & $\begin{array}{c}\text { Significant } \\
\text { at } 0.05 \\
\text { level }\end{array}$ \\
\hline & Urban & 360 & 14.555 & 8.319 & & & & & \\
\hline \multirow[t]{2}{*}{ Inquisitiveness } & Rural & 360 & 3.755 & 2.297 & 0.247 & 0.170 & 1.455 & 718 & $\begin{array}{c}\text { Not } \\
\text { Significant } \\
\text { at } 0.05\end{array}$ \\
\hline & Urban & 360 & 4.002 & 2.260 & & & & & level \\
\hline \multirow[t]{2}{*}{ Persistency } & Rural & 360 & 3.152 & 2.856 & 0.536 & 0.238 & 2.255 & 718 & $\begin{array}{l}\text { Significant } \\
\text { at } 0.05 \\
\text { level }\end{array}$ \\
\hline & Urban & 360 & 3.688 & 3.490 & & & & & \\
\hline
\end{tabular}

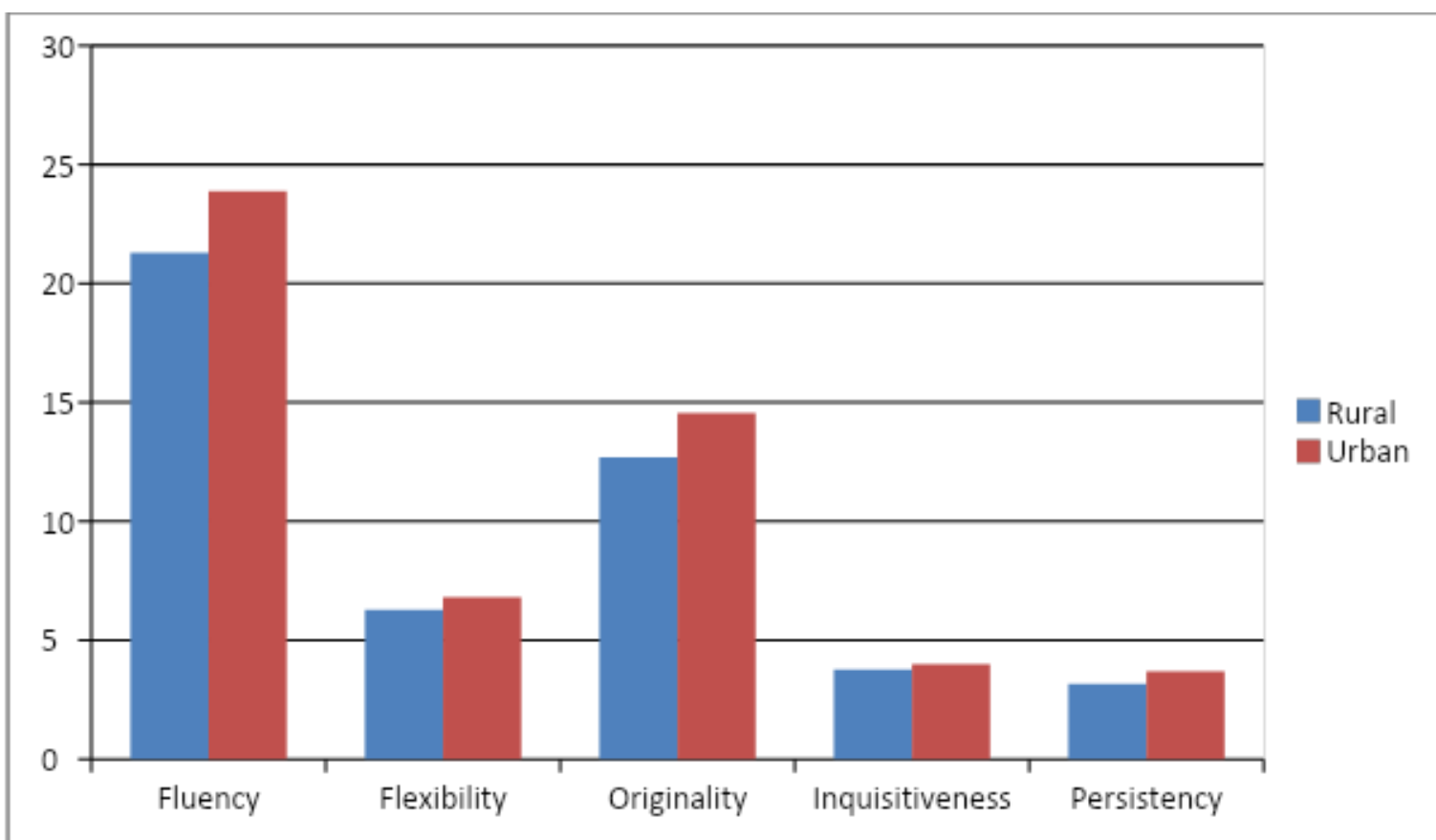

Figure 2: Comparison of Mean Scores on various dimensions of creativity between Rural and Urban Secondary school students of Dibrugarh district, Assam

Based on the descriptive statistics and the independent means t-test results presented in Table 4, fluency, flexibility, originality, and persistence were found to be significant at a $95 \%$ confidence level between the rural and urban secondary school students. The results of Table 4 also revealed that the students from urban secondary schools exhibited a higher level 
of creative ability in terms of fluency, flexibility, originality and persistency dimensions, while the students from rural secondary schools had a lower level of creative ability concerning fluency, flexibility, originality, and persistency dimensions. Furthermore, concerning the persistency dimension i.e. the ability to continue to strive for the sake of achievement despite fatigue or discouragement (Passi, 1979), our study reveals an interesting finding that students from rural and urban secondary schools have significant differences on their persistency aspect. Meanwhile, curiosity the synonym for inquisitiveness has been linked to creativity by many psychologists. Fromm who considered the capacity to be puzzled or to be surprised as an important attitudinal characteristic for creative development (Dacey \& Madaus, 1969), on this aspect, our study came up with an interesting finding. According to the results of Table 4, the $\mathrm{t}$-value $(\mathrm{t}=1.455)$ for the inquisitiveness dimension was found insignificant at $95 \%$ confidence level between rural and urban secondary school students, although urban secondary school students had a better mean inquisitiveness $(M=4.002)$ than the students from rural secondary schools. Hence, these results suggest that students from urban secondary schools were more creative in terms of fluency, flexibility, originality, inquisitiveness, and persistency dimensions than their rural counterparts. Therefore, it can be concluded that creativity as a multidimensional attribute is differentially distributed among students from rural and urban secondary schools of the Dibrugarh district of Assam. This implies that the creativity of secondary school students differs significantly concerning locale. Similar results were also reported by Patel (1999) who found that students of rural and urban locality differ significantly on their creative ability. The study carried out by Thabor (2003) also showed a significant difference in the creative thinking ability of rural and urban secondary school students. The research findings of Abirami (2012) also supported our research findings relating to the existence of a significant difference in the creative abilities of students from rural and urban secondary schools. This part of our research result is found contradictory with Bhogayata (1986) who revealed that urban and rural secondary school students did not differ significantly on their creative ability.

The results of the present research also revealed that students from urban secondary schools had a higher level of creative ability in terms of fluency, flexibility, and originality dimensions in comparison to their rural counterparts. These results are consistent with previous research conducted by Reddy (2015) who found urban high school students as a better scorer than their rural counterparts in all the dimensions of creativity such as fluency, flexibility, and originality. This research result is also consistent with research findings reported by Kumar \& Kumari (2014) who revealed the superiority of urban secondary school students over the rural students on the originality dimension of creativity.

\section{CONCLUSION}

This research work is concerned with the investigation of the creative abilities of students from rural and urban secondary schools in the Dibrugarh district of Assam. It came up with the result that there is a disparity in creative abilities among rural and urban secondary school students in the Dibrugarh district of Assam. Hence, it turned out that students belonging to rural and urban secondary schools may show differences in their creative abilities. The results indicate that students from urban secondary schools are better than their rural counterparts in all dimensions of creativity such as fluency, flexibility, originality, inquisitiveness, and persistence, although these two groups did not have statistically significant differences concerning the inquisitiveness dimension. Thus, it can be concluded that students hailing from urban secondary schools are more creative in comparison to the rural secondary school students.

\section{LIMITATION AND STUDY FORWARD}

With the understanding of rural-urban disparity concerning creativity, teachers, educators, and school authorities must provide more exposures and stimulating environment to Secondary Educational levels of students in schools especially rural background students. The present study however has its limitations. Hence, replication of this study in a diverse environment or in other samples might yield different results. Henceforth, future researchers may take up similar types of research studies in diverse settings or different sample groups. Additionally, the future researcher may even explore those factors which create differences in the creative ability of rural and urban Secondary level school students.

\section{ACKNOWLEDGMENT}

The authors of the paper would like to express their sincere gratitude to all the Headmasters, Headmistresses \& Principals of different Secondary schools of Dibrugarh district of Assam for their kind help in organizing and administering the Passi Test of Creativity on sampled students. We would also like to express our sincere gratitude to all the Students who had cooperated and participated with us in carrying out this research study.

This research was not financially supported by any organization.

\section{AUTHORS' CONTRIBUTION}

Manisha Das is a registered Ph. D scholar in the Department of Education under Dibrugarh University and an Assistant Professor in the Department of Education, Dibrugarh University. In this study, she was a member whose job was confined in 
writing the introduction, review of related literature of the manuscript, methodology of the study, collection of research data, processing, and analysis of data.

Mukut Hazarika, is a Professor in the Department of Education, Dibrugarh University. As the Research Supervisor, this research work was carried out under his guidance as a part of the Ph. D work by Manisha Das. He was a member of designing the title of this research as well as reviewed the final manuscript.

\section{REFERENCES}

1. Abirami, R. (2012). A study of creativity of high school students in relation to information processing style, conformity behavior, and self-confidence. (Doctoral dissertation). http://www.vinayakamission.com.

2. Abraham, A. (2015). Gender and creativity: an overview of psychological and neuroscientific literature. Brain Imaging and Behavior. https://doi.org/10.1007/s11682-015-9410-8

3. Ahmadi, N. \& Besançon, M. (2017). Creativity as a stepping stone towards developing other competencies in classrooms. Education Research International. https://doi.org/10.1155/2017/1357456

4. Ai, X. (1999). Creativity and academic achievement: An investigation of gender differences. Creativity Research Journal, 12(4), 329-337, https://doi.org/10.1207/s15326934crj1204_11

5. Almeida, L. S., \& Wechsler, S. M. (2015). Excelência profissional: a convergência necessária de variáveis psicológicas. Estudos de Psicologia (Campinas), 32(4), 763-771. http://dx.doi.org/10.1590/0103166X2015000400019.

6. Beghetto, R. A., \& Kaufman, J. C. (2014). "Classroom contexts for creativity". High Ability Studies, 25(1), 5369. https://DOI:10.1080/13598139.2014.905247.

7. Bhogayata, C.K. (1986). A study of the relationship amongst creativity, self-concept, and locus of control. (Unpublished doctoral dissertation) Saurashtra University, Gujarat.

8. Bono, E.de. (2000). Six thinking hats. Penguin Random House.

9. Chauhan, S. \& Sood, M. (2018). A study of non-verbal creativity among secondary school students in relation to gender and locale. International Journal of Advanced Research and Development, 3(2), 1413-1418.

10. Csikszentmihalyi, M. (2013). Creativity- the psychology of discovery and invention. HarperPerennial Modern Classics.

11. Dacey, J.S. \& Madaus, G.F. (1969). Creativity: definitions, explanations, and facilitation. The Irish Journal of Education, 3(1), 55-69. http://www.jstor.org/stable/30076685

12. Das, A. (2012). A Study on emotional intelligence in relation to creativity, stress, and academic achievement at the B.Ed level. (Doctoral dissertation). http://hdl.handle.net/10603/28285

13. Drevdahl, J.E. (1956). Factors of importance for creativity. Journal of Clinical Psychology, 12(1), 21-26. https://doi.org/10.1002/1097-4679(195601)12:1<21::AID-JCLP2270120104>3.0.CO;2-S

14. Eisler, R., Donnelly, G., \& Montuori, A. (2016). Creativity, society, and gender: Contextualizing and redefining creativity. Interdisciplinary Journal of Partnership Studies, 3(2). https://doi.org/10.24926/ijps.v3i2.130

15. French, J.L. (1959). Educating the Gifted: A book of readings. Holt, Rinehart, and Winston, Inc.

16. Götz I.L.(1981). On defining creativity. The journal of aesthetics and art criticism, 39 (3), 297-301. https://doi.org/10.2307/430164

17. Guilford, J. P. (1962). Factors that aid and hinder creativity. Teachers College Record, 63, 380-392.

18. Guilford, J. P., Wilson, R. C. \& Christensen, P. R. (1952). A factor-analytic study of creative thinking, II. Administration of tests and analysis of results. (Psychological Laboratory Reports No. 8). University of Southern California.

19. Guilford, J.P. (1958). Can creativity be developed? Art education, 11 (6), 3-18. https://doi.org/10.2307/3184459

20. Guilford, J.P. (1968). Intelligence, creativity, and their educational implications. Robert R. Knapp.

21. Haefele, J.W. (1962). Creativity and innovation. Reinhold Publishing Company. https://www.worldlibrary.net

22. Han, W., Zhang, M., Feng, X., Gong, G., Peng, K., \& Zhang, D. (2018). Genetic influences on creativity: An exploration of convergent and divergent thinking. PeeJ 6:e5403; https://doi.org/10.7717/peerj.5403

23. Hildreth, G.H. (1966). Introduction to the gifted. McGraw-Hill Book Company.

24. Iandoli, C.C. (1994). Creativity revisited: a synopsis of theories of creativity since 1950. The Journal of Technology Studies, 20 (2). http://www.jstor.org/stable/43741568

25. Jha, A.S. (2012). A study of creativity of the high school students in relation to certain variables. Creative and Related Factors, 1 (2),1-5. http://www.voiceofresearch.org

26. Joseph, B.A.(2015).Emotional intelligence, creativity, and school adjustment as factors influencing academic achievement of secondary school students of Northern Kerala. (Doctoral dissertation). http://hdl.handle.net/10603/49969

27. Kalita, P. (2013). A study of creativity among adolescents in relation to select a variables-cognitive ability, socioeconomic status, and personality pattern. (Doctoral dissertation). http://hdl.handle.net/10603/115297 
28. Kaufman, J.C. \& Sternberg, R.J. (2007). Creativity. Change, 39(4), 55-58. https://doi.org/10.3200/CHNG.39.4.55$\mathrm{C} 4$

29. Kim, K.H. (2019). Demystifying creativity: What creativity isn't and is?, Roeper Review, 41(2), 119-128. https://doi.org/10.1080/02783193.2019.1585397

30. Kumar, L. \& Kumari, P. (2014). A study of originality among secondary school students in relation to locale, ethnicity, types of institutions, and sex. People's Dialogue on Education, 6 (2). https://www.academia.edu

31. Kumar, L. \& Kumari, P.(2016). A study of convergent thinking and divergent thinking among secondary school students in relation to ethnicity, locale, types of institutions, and sex. Journal of Indian Education, XXXI (4). https://www.academia.edu

32. Kupers, E., Wermser, A.L., McPherson, G., \& Geert, P. (2019). Children's creativity: A theoretical framework and systematic review. Review of Educational Research, 89(1), 93-124. https://doi.org/10.3102/0034654318815707

33. Lin, Y.S. (2011). Fostering creativity through the education-A conceptual framework of creative pedagogy. Creative Education, 2(3), 149-155. https://doi.org/10.4236/ce.2011.23021

34. Mehta, J. \& Khajuria, J. (2018). Creative thinking of middle school students in relation to their socio-economic status and intelligence. International Journal of Research in Social Sciences, 8(4), 862-871. http://www.ijmra.us

35. Nakano, T.C. \& Wechsler, S.M. (2018). Creativity and innovation: Skills for the $21^{\text {st }}$ century. Estudos de Psicologia (Campinas), 35(3), 237-246. https://doi.org/10.1590/1982-02752018000300002

36. Parnes, S.J. (1961). Can creativity be increased? Studies in Art Education, 3 (1), 39-46. https://doi.org/10.2307/1319527

37. Passi, B.K. (1979). Manual for Passi test of creativity-verbal and non-verbal. National Psychological Corporation.

38. Patel, K.S. (1999). A comparative study of the creativity of the B.C. and Non-B.C. students of secondary schools of Kaira district in relation to their institutional climate. (Doctoral dissertation), Gujarat University, Ahmedabad.

39. Plucker, J. A., \& Renzulli, J. S. (1999). Psychometric approaches to the study of human creativity. In R. J. Sternberg (Ed.), Handbook of creativity (pp.35-61). Cambridge University Press.

40. Prakash, V.(2007). Creative learning. Viva Books Private Ltd.

41. Reddy, K, J.(2015). Creativity in relation to certain psychosocial factors among high school students. (Doctoral dissertation). http://hdl.handle.net/10603/119807

42. Reddy, K.J., Viswanath, K. \& Reddy, S.V. (2015). Impact of demographic variables on nonverbal creativity among high school students. The International Journal of Indian Psychology, 2(4).

43. Rhodes, M. (1961). An Analysis of Creativity. The Phi Delta Kappan, 42. (7), 305-310. http://www.jstor.org/stable/20342603

44. Rogers, C.R. (1954). Toward a theory of creativity. ETC: A Review of General Semantics, 11 (4), 249-260. https://www.jstor.org/stable/42581167

45. Runco, M.A. \& Jaeger, G.J. (2012).The standard definition of creativity. Creativity Research Journal, 24(1), 9296. https://doi.org/10.1080/10400419.2012.650092

46. Runco, M.A., Noble, E.P., Palmon, R.R., Acar, S., Ritchie, T., \& Yurkovich, J.M. (2011). The genetic basis of creativity and ideational fluency. Creativity Research Journal, 23(4), 376-380. https://doi.org/10.1080/10400419.2011.621859

47. Shaheen, R. (2010). Creativity and education. Creative Education,1(3), 166-169. https://doi.org/10.4236/ce.2010.13026

48. Simpson, R.M. (1922). Creative imagination. The American Journal of Psychology, 33(2), 234-243. https://doi.org/10.2307/1414133

49. Sternberg, R.J. \& Kaufman, J.C. (2018).The nature of human creativity. Cambridge University Press. https://doi.org/10.1017/9781108185936

50. Sudhir, M.A., \& Khiangte, V. (1997).Personality and creativity among secondary school students: A study in talent development. Indian Educational Review, 32, 115-125.

51. Surapuramath, A.K. (2014). A study of the relationship between creativity and academic achievement of secondary school pupils. International Journal of Social Science, 3, 305-309. https://ndpublisher.in/admin/issues/IJSSVSh.pdf

52. Thabor, R. (2003). Creative thinking ability and attitude towards science among students of secondary schools having different organizational climates. (Doctoral dissertation). http://www.dspace.nehu.ac.in

53. Torrance, E. P. (1995). Why fly? A philosophy of creativity. Praeger.

54. Torrance, E.P. \& Shaughnessy, M.F. (1998). An interview with E.Paul Torrance: about creativity. Educational psychology review, 10 (4), 441-452. https://doi.org/10.1023/A:1022849603713

55. Wu, M., Siswanto, I., \& Solikin, M. (2018). Cultivating student creativity-A qualitative study of outstanding students of Yogyakarta state university. Education, 8(1), 1-4. 